\title{
Pre-Service Teachers' Experiences and Views on Project-Based Learning Processes
}

\author{
Funda Dag ${ }^{1} \&$ Levent Durdu ${ }^{1}$ \\ ${ }^{1}$ Faculty of Education, Kocaeli University, Kocaeli, Turkey \\ Correspondence: Funda Dag, Faculty of Education, Kocaeli University, Kocaeli, 41380, Turkey. Tel: \\ 90-262-303-2456. E-mail: fundadag@kocaeli.edu.tr
}

Received: February 3, 2017

Accepted: March 5, 2017 Online Published: June 27, 2017

doi:10.5539/ies.v10n7p18

URL: https://doi.org/10.5539/ies.v10n7p18

\begin{abstract}
Project-based learning (PjBL) has been promoted as an effective and frequently used student-centered learning approach for various learning environments. To have various learning experiences with $\mathrm{PjBL}$ is an important requirement for pre-service teachers (PSTs). The purpose of the study was to investigate the experiences PSTs had with group work and collaboration, resources and research methods, the problems they faced, and the strategies they used to overcome these problems during the information and communications technology (ICT)-integrated PjBL process, as well as their thoughts concerning learning processes in PjBL. The participants in the study consisted of 413 PSTs in six different teaching programs who took the course Computer 2. Qualitative methods were used in this descriptive study. The results revealed that PSTs perceived the PjBL processes mostly positively and also that they thought the PjBL process contributed to their learning and helped them gain PjBL skills. PSTs formed groups based on their own preferences. PSTs perceived that the PjBL process based on group work that was implemented advanced their problem-solving and collaboration skills.
\end{abstract}

Keywords: project-based learning, group-based learning, teaching and learning strategies, student-centered learning, PST education

\section{Introduction}

Every individual should have the ability to "learning how to learn" (Collins \& Halverson, 2009; Nosbush, 2006) in the information age, where information spreads very quickly and the amount of information available is constantly increasing. In addition, critical thinking and problem-solving have come to be frequently required competences (Bellanca \& Brandt, 2010). To make sure their employees have skills suitable for the twenty-first century, governments around the world have started to reform their educational policies (Amiel \& Reeves, 2008; Özdemir \& Kılıç, 2007), starting with making sure the goal of education systems is learning rather than teaching. In this sense educational institutions are seen as places where learning takes place, not simply places where content is "transferred." To that end, contemporary education systems began to adopt the constructivist philosophy of education, which suggests, in general, that students should be able to manage their own learning processes, deal with real-life problems, and undertake complex projects and should have the advantages of technology-enhanced learning environments (Savery \& Duffy, 1996). To this end, student-centered teaching methods have come into prominence. Student-centered learning approaches aim to create learning environments that are based on constructivist and social-cognitive learning theories and are built to ensure active student participation. The student assessment is authentic and based on performance in these environments (Arends, 2012; Hannafin, Hill, \& Land, 1997; Land \& Hannafin, 2000).

According to the constructivist paradigm, learners must have responsibilities and control their learning processes (Hannafin, Land, \& Oliver, 1997). In the learning process, learners link new knowledge with previous knowledge in what is called the knowledge construction process. During the process of knowledge creation, learners overcome problems and related complex tasks by interacting with peers, instructors, and technology and by using their learning capabilities (Abdulwahed, Nagy, \& Blanchard, 2008).

Implementing constructivist learning approaches in educational environments requires teachers and students to change their roles. Teachers are required to create meaningful problem (or project) situations and are expected to guide and assist learners rather than fall back on teacher-oriented or other traditional teaching approaches. In addition, students should be active during the learning process, reflecting on the learning process and gaining 
experience, thereby learning how to learn. Thus, throughout this process, students are involved in searching for and finding knowledge from different sources, organizing and sharing this knowledge with their friends in various formats, preparing projects individually or collaboratively, and participating in activities like cooperative work with their friends in the knowledge construction process (Jonassen, 1995). In other words, constructivist learning environments require more student-centered, more interactive, and more collaborative teaching-learning activities.

\subsection{Project-Based Learning}

There are various instructional methods that adopt the constructivist learning paradigm in order to present meaningful opportunities for learning through hands-on activities or projects that promote active knowledge construction (Jonassen, 1998). One of these methods is project-based learning (PjBL), which is a constructivist pedagogical practice and one of the student-centered teaching techniques.

"Project-based learning is a dynamic classroom approach in which students actively explore real-world problems and challenges and acquire a deeper knowledge" (Edutopia, 2014, p. 1). PjBL is based on the development of a design and continuous formative evaluation of the learning process (Erdem, 2002). In this process, learners plan their own learning process individually or as a group, and then they research, collect and analyze information, work in collaboration, and ultimately take responsibility for their own learning (Erdem \& Akkoyunlu, 2002; Morgan, 1987). From the teachers' perspective, this method is a student-centered learning approach that requires students to work on real-life problems so that they can construct their own knowledge about the relations between interdisciplinary subjects. This requires instructors to design a project-based learning environment and guide students during the PjBL processes (Demirhan, 2002; Kalayc1, 2008).

It is worth noting that a project generally begins with analyzing the problem, collecting and organizing information, prototyping a solution, and finally developing a product (Jones, Rasmussen, \& Moffitt, 1997; Thomas, Mergendoller, \& Michaelson, 1999). In somewhat more detail, during a PjBL process, students first analyze the problem and conduct intensive research into the relevant subject (Diffily, 2002). Afterwards, students analyze the collected information, organize and synthesize it, and use their imagination and creativity to develop a design. Finally, they develop a product based on their design. The product can take various forms, including a presentation, a poster, a book, software, a mechanical tool, a vehicle, and so on. Students develop their problem-solving skills and high-level cognitive skills (i.e., analysis, synthesis, and implementation) during these phases (Kılıç, 2009). In addition, students develop project-management skills, including time-management and taking responsibility for their own learning (Cunha, 2005).

Various studies have demonstrated the efficiency of PjBL in higher education (de Los Rios, Cazorla, Díaz-Puente, \& Yagüe, 2010; Pinho-Lopes \& Macedo, 2016) and also in teacher education programs (Cavanaugh, 2004; Fox \& Snape, 2011; Hartescu, 2013; Lavy \& Shriki, 2008; Marshall, Petrosino, \& Martin, 2010). Pre-service teachers (PSTs) transfer their knowledge, experience, attitudes, and affective gains to their future professional lives. They teach in the way they learnt (Yıldirım, 2000). A study conducted by Cavanaugh (2004) revealed that if prospective teachers experience student-centered learning methods like PjBL, they have opportunities to develop an extensive repertoire of teaching strategies to implement in their classrooms (Cavanaugh, 2004). A study conducted by Lavy and Shriki (2008) that was aimed at exploring how learning via computerized PjBL changed the views of pre-service mathematic teachers regarding the image of the good teacher shows that information and communication technology (ICT)-integrated PjBL is an effective learning approach for helping promote a change in views of the PSTs regarding the image of the good teacher. In addition, a study conducted by Marshall, Petosino, and Martin (2010) ascertained that although PSTs held superficial views of PjBL, they reported time and curriculum restrictions as major barriers to $\mathrm{PjBL}$. The researchers furthermore claimed that a PjBL process should be presented with an explicit learning goal and that instructor(s) must provide the necessary intellectual scaffolding for students and give them support throughout the PjBL process. Thus, it could be said that PjBL and similar constructivist learning methods are essential for teacher education programs, and $\mathrm{PjBL}$ can be considered an effective learning method for the development of the learning skills of PSTs. It also develops PSTs' teaching skills for their professional lives. In this context, it can be said that it would be beneficial to examine how the implementation of PjBL affects PSTs in order to discover what characteristics make someone a successful practitioner of $\mathrm{PjBL}$.

The PjBL process allows for students to work on projects both individually and in groups. The decision of whether the project is going to be individual or group based on such factors as the scope and the preparation time of the project. When the time and effort students spend on projects are considered, it can be said that most project work requires individual study by students (Cunha, 2005). But in PjBL, working in groups is preferred 
because it contributes to the development of students' collaboration and communication skills. The study conducted by Lang (2005) states that ICT-integrated and group-based PjBL is helpful for PSTs for improving their awareness of their own thought processes and it also supports them in forming their own habits of critical, creative, and self-regulated thinking. He also affirmed that the PjBL process, which is based on designing meaningful projects for students and planned online discussion forums, ensured the development of PSTs' collaborative working skills.

Though there are clear advantages to working in groups in $\mathrm{PjBL}$ processes in terms of what is learnt about a subject and affirmative attitudes (Lou, Abrami, \& d'Apollonia, 2001; Springer, Stanne, \& Donovan, 1999), it can be difficult to implement and evaluate PjBL based in group work (Cheong, 2010). So, one of the most important components in the implementation of the PjBL is the streamlining of the form that group work takes (Livingstone \& Lynch, 2000). To gain a better understanding of the effectiveness of PjBL, group composition and processes in small group work should be investigated (Cheng, Lam, \& Cham, 2008; Lang, 2005).

On the other hand, using information and communication technologies (ICTs) for teaching and learning has become an essential skill for teachers. Use of technology in learning environments not only allows for more effective teaching/learning processes, but it also requires new technological skills from teachers and students (Karaca, 2011; Cavanaugh, 2004). For this reason, teacher education programs should include opportunities for PSTs to pick up ICT skills, not only for learning but also for teaching. ICTs provide a variety of powerful tools for teachers and students for research, design, collaboration and communication, and information-sharing. In this context, effective ICTs also help create effective learning environments for constructivist learning approaches like PjBL in various ways. Firstly, a variety of powerful ICTs such as authoring tools, multimedia tools, and office programs can be used to design and develop various project outputs (e.g., see Lavy \& Shriki, 2008). Second, ICTs can be used to create learning and teaching environments that facilitate learning. For example, an online learning environment allows access to learning sources and activities from anywhere and anytime (Wang, 2008). It also supports online interactions between students and teachers via forums and messaging systems (e.g., see Ching \& Hsu, 2010; Lou \& MacGregor, 2004; and Raes \& Schellens, 2016). Work with ICTs can constitute all or part of a project; for example, web site design, hypermedia design, or designing a digital video could be a whole or part of the project (e.g., see Cavanaugh, 2004; and Shi, Reeder, Slater \& Kristjansson, 2004). In today's educational system, teachers are expected to implement student-centered learning methods and use technology effectively in their courses (Bagley \& Hunter, 1992). With all of this in consideration, in this study a PjBL environment, where technology was taught and also used as a medium, was designed and implemented.

In this study, to examine how the implementation of PjBL affects the opinions and thinking of PSTs who are from different educational programs, a PjBL environment was designed for PSTs expected to construct their own knowledge about common educational software formats. The PjBL environment was designed for the course Computer 2, which was a basic educational technology course for teacher education programs in Turkey. In Computer 2, PSTs were taught about instructional technology and they worked in groups to develop web-based instructional materials related to their subject area.

In the PjBL process, ICT was used not only to facilitate learning about technology but also to facilitate learning with technology. ICT was used as a part of the course objective (designing an educational web site) and also as part of the learning and collaboration environment (as the learning management system [LMS] via forums). Students participated in face-to-face sessions and an e-learning environment. In the PjBL process, PSTs worked in small groups and designed web-based instructional software related to their teaching area. In face-to-face sessions, students presented progress reports on their projects to the course instructor and received advice. They used an LMS to stay on schedule, and course materials (presentations and other materials) and the forum were used to share problems and ideas encountered in their work on their projects.

In light of this arrangement, we undertook a detailed investigation of the experiences and views of PSTs about the PjBL process, including how the PjBL process contributed to the PSTs' learning, how they formed groups and organized group work, and how they used ICT.

In the first phase of our study (Dağ \& Durdu, 2012), we investigated the PSTs' views about academic achievement, research skills, resource and time-management skills, and group work and collaboration skills with headings based on the PjBL steps defined by Erdem and Akkoyunlu (2002). The results of the initial study revealed that the PjBL process helped PSTs in terms of research and resource-management skills and had a positive impact on their learning and course achievement. Also, PSTs perceived the PjBL process as having a positive effect on their group work and collaboration skills. On the other hand, they reported that although PSTs' in-group communication was good, they had some problems in sharing the project workload and responsibilities. 
Similar problems were reported concerning time-management issues during the $\mathrm{PjBL}$ process.

In this study, based on the findings of the first phase, PSTs' thoughts concerning the PjBL process were investigated in detail. Within this framework, an investigation was made of the PSTs' overall evaluation of the $\mathrm{PjBL}$ process, their preferences when forming groups, the problems they faced during the PjBL processes and their solutions to these problems, their research methods, and the resources they utilized. Overall, this study might provide guidance to instructors designing PjBL environments, teacher education programs, and researchers utilizing instructional technology with learner-centered approaches and PjBL.

\subsection{Research Problem}

This study aimed to investigate the PjBL process from PSTs' perspective. A PjBL environment was designed for the course Computer 2, a course for PSTs about instructional technology. They worked in groups to develop web-based learning material related to their subject area. This study investigated the following research questions:

1) What are the experiences and views of PSTs concerning how the PjBL process affected them?

2) What are the experiences and views of PSTs towards improving the PjBL process?

3) What are the problems PSTs faced, and what strategies did they find to solve them?

4) What resources and research methods did the PSTs use to develop the final products of their projects?

5) What are the criteria that determine PSTs' preferences and difficulties when forming groups?

6) Is there a connection between PSTs' preferences when forming groups and problems they faced while working in groups?

\section{Method}

This study was designed as a descriptive case study in which persons, incidents, and processes were investigated with a comprehensive approach, usually by asking questions (Johnson \& Christensen, 2004; Wallace \& Poulson, 2003; Y1ldırım \& Şimşek, 2008) of what is or was (Brickman \& Rog, 1998). This study focuses on processes rather than outcomes and on the case rather than a specific variable (Merriam, 1998).

\subsection{Context}

The context of the study was Computer 2, a requisite course for PSTs. The aim of the course was to integrate technology into classroom teaching. In Computer 2, PSTs learn how to support classroom instruction with technology as well as examples, common educational software formats (e.g., tutorials, drill and practice, simulations, computer games, web-based learning environments, computer-based tests).

Computer 2 was an ICT-integrated course where students participated in face-to-face sessions and an e-learning environment. Face-to-face sessions included instructors' presentations and laboratory activities. PSTs could access course materials (presentations and other documents), a schedule of activities, and a forum via an LMS. In order to provide a student-centered learning environment, a PjBL environment was designed. The goal was for PSTs to construct their own knowledge based on the theoretical background presented by the instructor.

During the first eight weeks of the course, the instructors taught educational technology concepts, applications of computer-based instruction, common educational software formats, and the basics of web design. In the ninth week, PSTs were informed about the projects and were asked to form project groups (preferably three people per group, with a maximum of four) and select their project theme. PSTs developed a project for the following five weeks. In the last week of the semester they presented their projects to all classmates.

The study was carried out with PSTs from six different educational programs and the information about them is presented in the next section. Every individual educational program had an average of 17 project groups. There were 10 project themes, and each project theme could be selected by a maximum of two groups in each educational program in order to prevent all the groups from selecting the same project theme. After selecting their project themes, project groups were each expected to select a topic for their projects. The topics had to be appropriate for their educational program. Therefore, PSTs selected their project topics from the primary education curriculum provided by the Turkish Ministry of National Education (MoNE). Afterwards, the project phases and the requested tasks for these phases were explained by the instructors.

Figure 1 presents the weekly course schedule and the implementation of the project. Every week, project groups presented their work and submitted a report and received feedback. With these face-to-face sessions, the instructor guided the students, indicated what was still missing from their project work, and explained what was expected for the next phase of the project. During the five weeks of the project, PSTs had the opportunity to 
share their knowledge and problems via the LMS.

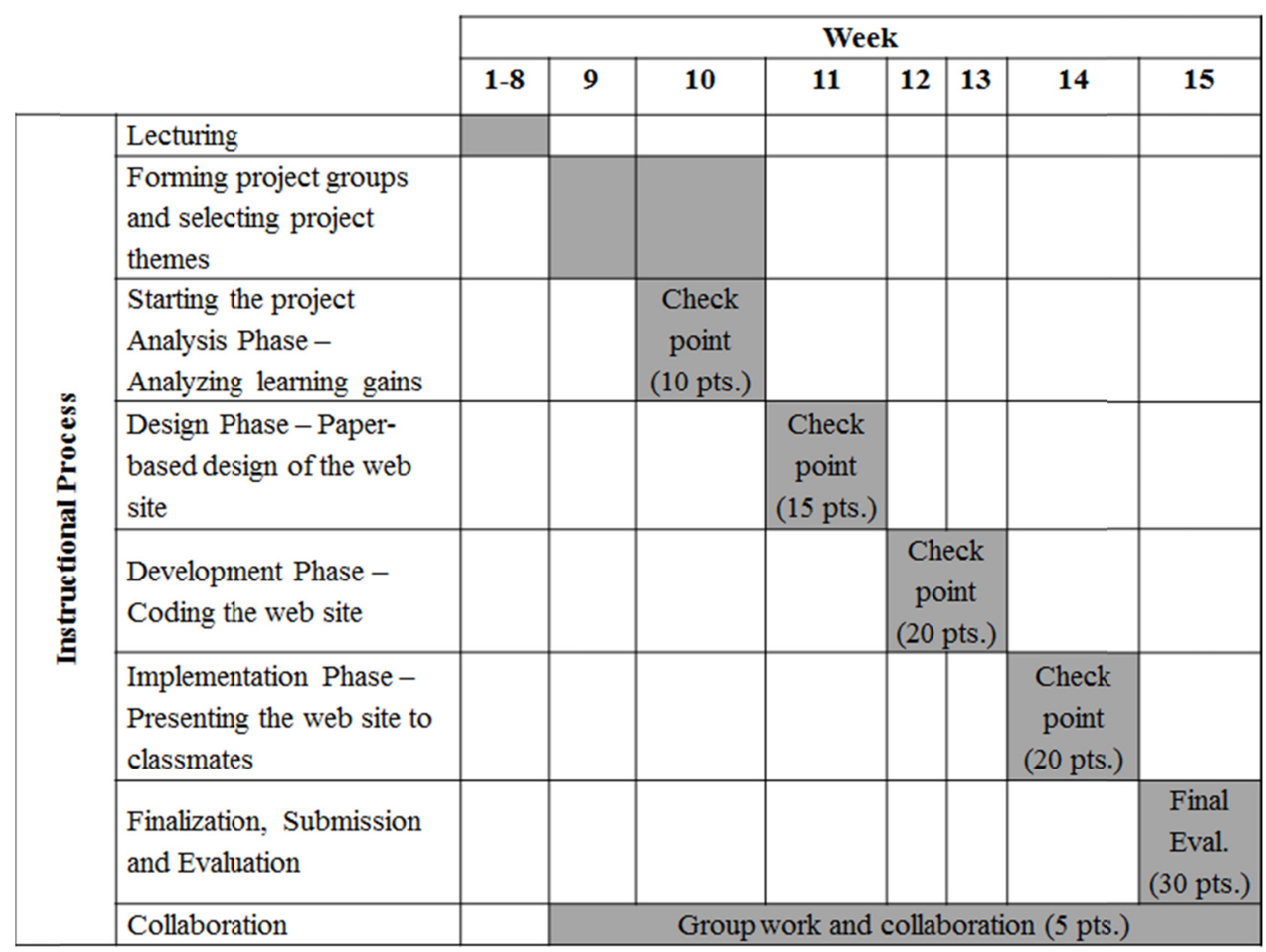

Figure 1. Weekly course schedule and project implementation

\subsection{Participants}

Four hundred and thirteen (413) PSTs from various educational programs (science education, English language education, mathematics education, pre-school education, primary school education, and psychological counselling and guidance) at the Faculty of Education of a large state university participated in the study. PSTs who were taking Computer 2 for the first time and volunteered to participate in the study were included. Table 1 shows the statistical distribution of the participants. Female participants were unsurprisingly outnumbered by their counterparts, as it is a common finding in our research that women pursue teaching as a profession more than men do.

Table 1. Information about the participants of the study

\begin{tabular}{lcc}
\hline Property & Number (f) & Percentage (\%) \\
\hline Gender & & \\
Female & 333 & 80.63 \\
Male & 80 & 19.37 \\
Total & 413 & 100 \\
\hline Program & & \\
\hline Science education (SE) & 65 & 15.74 \\
English language teaching (ELT) & 57 & 13.80 \\
Mathematics education (ME) & 99 & 23.97 \\
Pre-School education (PSE) & 54 & 13.08 \\
Primary school education (PE) & 90 & 21.79 \\
Psychological counselling and guidance (PCG) & 48 & 11.62 \\
Total & 413 & 100 \\
\hline
\end{tabular}




\begin{tabular}{lcc}
\hline Project Theme & & \\
\hline P1- Electronic encyclopedia & 59 & 14.29 \\
P2- Tutorials & 41 & 9.93 \\
P3- Drill and practice & 44 & 10.65 \\
P4- Hypermedia system & 46 & 11.13 \\
P5- Educational games (introductory web site) & 48 & 11.62 \\
P6- Simulations (introductory web site) & 36 & 8.72 \\
P7- Computer-based educational software (introductory web site) & 52 & 12.59 \\
P8- Designing educational games & 30 & 7.26 \\
P9- Concept map & 31 & 7.51 \\
P10- Storyboard & 26 & 6.30 \\
\hline Total & 413 & 100 \\
\hline
\end{tabular}

\subsection{Data Collection}

The data collection instrument of this study included nine open-ended questions. The questions were developed based on a review of the literature and on researchers' previous experiences concerning PjBL environments. The instrument was checked by a field expert concerning content and a language expert concerning grammar. Before finalizing the instrument, five students who had taken Computer 2 the previous year were requested to examine the questions considering the purpose of the study. Students expressed that the questions were clear and understandable. The questions were as follows:

Q1) Please, explain the project process. (Consider the negative and the positive aspects of the process. Comment on your group's performance during the project process from beginning to the end.)

Q2) What do you think about how the project affected you?

Q3) How did this project process affect your opinions about the course?

Q4) What kind of problems did you face during the project processes? What did you (either individually or as a group) do to solve these problems you faced?

Q5) Which information sources did you use for your project?

Q6) How did you classify the information at hand and how did you use the information for your project?

Q7) How did you form your group? (Please, express the criteria that affected the selection of your group members?)

Q8) How did the problems emerge during your group work and how did the harmony of your group affect your performance of project work?

Q9) Is there any other thing you want to express?

Q1 and Q2 were asked for the first research problem to reveal the experiences and views of PSTs concerning the PjBL process and how it affected them. Q3 was asked for the second research problem to obtain the views of PSTs about how the PjBL process might be improved. Q4 was asked for the third research problem to discover the problems PSTs faced and their strategies for solving them. Q5 and Q6 were asked for the fourth research problem to learn about the resources and research methods that PSTs used to develop their project's final product. Q7 and Q8 were asked for the fifth research problem to reveal the criteria that determine PSTs' preferences and difficulties when forming groups. In addition, the results of the content analysis of Q7 and Q8 were also used for the sixth research problem in order to reveal any connection between PSTs' preferences when forming groups and problems they faced while working in groups. Finally, Q9 was asked to clarify the views of the students by allowing them to explain their opinions beyond what was allowed for by the questions.

The PSTs answered the questions online in the laboratory under the supervision of the instructors after all grades about their project work were announced in order to minimize their anxiety concerning grades. It is generally held that taking opinions in written form imposes limitations in qualitative studies. On the other hand, in order to reach all students and maximize the diversity of the answers, the data was collected online. By applying this strategy, researchers maximized the number of students they were able to obtain opinions from as well as the number of different educational programs and project themes represented.

\subsection{Data Analysis}

The open-ended questions were subjected to content analysis, which "is particularly suitable when analyzing 
documents e.g. newspaper texts, responses to open-ended questions" (Hancock, Ockleford, \& Windridge, 2009, p.14). Content analysis is a method where collected data is analyzed systematically for categorization and classification wherein the research subject (e.g., individual, group, organization, process and incident) can be discovered and described (Stemler, 2001; Yıldırım \& Şimşek, 2008).

Coding for content analysis can be done through two different strategies. The first strategy includes coding and recoding the data to discover themes (Haney, Russel, Gulek, \& Fierros, 1998). The second strategy includes coding the data based on some predetermined codes or themes concerning the theoretical and conceptual structure of the study. Both strategies offer the opportunity to revise and update the code and themes as required (Weber, 1990). The content analysis used in this study followed the latter strategy. In this context, eight main themes were determined based on research questions after discussion and consensus between the two researchers. Table 2 shows the main themes and their relationships with the research questions.

After determining the main themes, the data was subjected to content analysis. The collected data was defined as 413 cases in the Nvivo 8 software. Attributes such as department, gender, project theme, and education type were assigned for every case (Kuş-Saillard, 2009). Every case was read carefully and meaningful text was coded under a related main theme. During the coding process, sub-themes under a main theme were created as similar codes emerged from the text of cases. The eight main-themes $(1,2, \ldots, 8)$, nine sub-themes $(1.1,1.2,2.1, \ldots$, 8.3), and codes (e.g., the project was very comprehensive) that emerged from the data analyses are presented in Table 2. As the number of opinions coded is quite large (out of 92), code examples with the most views compiled under them are presented in Table 2.

Table 2. Main themes, sub-themes, and codes that emerged from content analysis

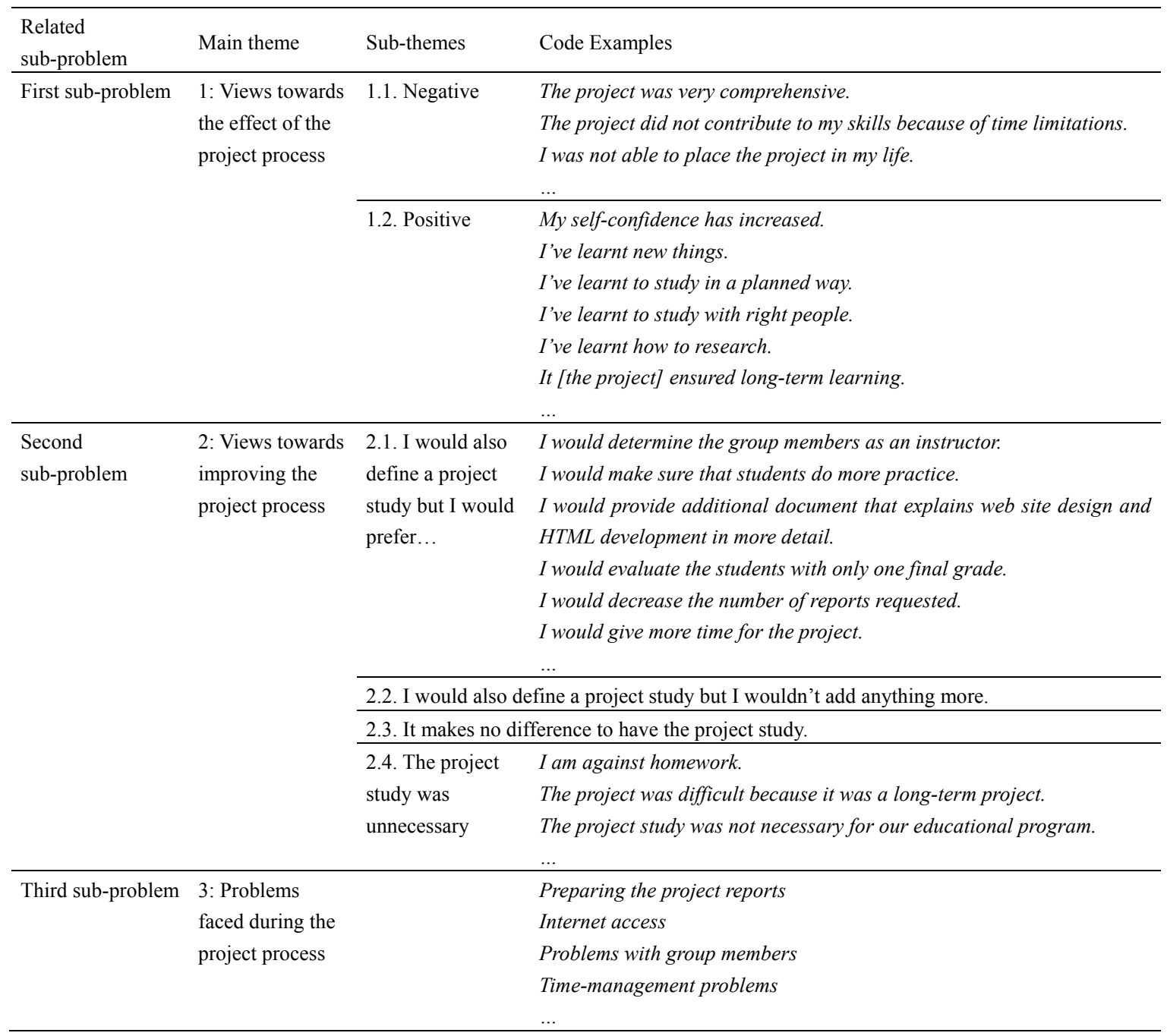




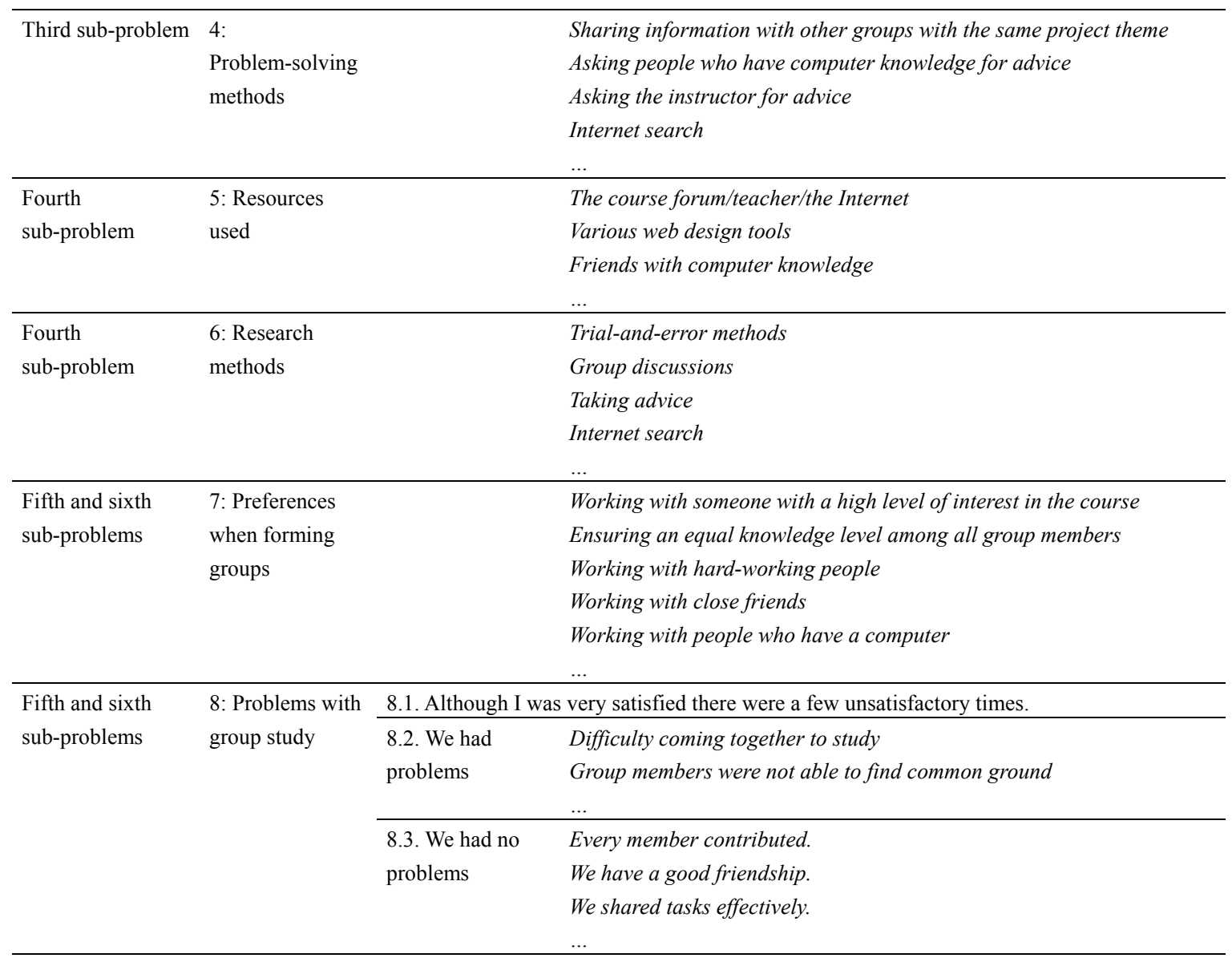

Content analysis was completed in two phases. The aim of the first phase was to ensure the reliability of the coding process. The researchers analyzed 60 points of data (10 cases from each educational program, with each case representing a different project theme) in detail by following a strategy that guaranteed maximum variation in the sample. Because the reliability of content analyses mostly depends on the coding process, the coding process was carried out by two researchers and the agreement percentage was calculated using the formula agreement percentage $=$ [agreement $/($ agreement + disagreement $)] \times 100($ Miles \& Huberman, 1994).

As can be seen from Table 3, agreement percentage values were found to be over $70 \%$ for all themes, and the total agreement percentage was $83 \%$. As the calculated agreement percentages are over $70 \%$ it can be said that the coding process was reliable (Miles \& Huberman, 1994). After ensuring the reliability of the coding process, the analysis of the rest of the data was done individually. The analysis of data was completed over a period of about six months. While presenting quotes from participants, numbers were used to represent participant number, and letters in parenthesis were used to represent the educational program of the participant, as explained in Table 1 above.

Table 3. Agreement percentage values of the codes

\begin{tabular}{llc}
\hline Themes & \multicolumn{2}{l}{ Agreement percentage } \\
\hline 1:Opinions concerning how the project process affected them & $14 /(14+4) \times 100$ & $78 \%$ \\
2:Opinions concerning improving the project process & $18 /(18+3) \times 100$ & $86 \%$ \\
3:Problems faced during the project process & $7 /(7+2) \times 100$ & $78 \%$ \\
4:Problem-solving methods & $9 /(9+1) \times 100$ & $90 \%$ \\
5:Resources used & $5 /(5+1) \times 100$ & $83 \%$ \\
6:Research methods & $4 /(4+0) \times 100$ & $100 \%$ \\
7:Preferences when forming groups & $11 /(11+2) \times 100$ & $85 \%$ \\
8:Problems with group study & $8 /(8+3) \times 100$ & $72 \%$ \\
Total & $76 /(76+16) \times 100$ & $83 \%$ \\
\hline
\end{tabular}




\section{Research Findings}

The findings are presented here in tables, models, and matrices. The tables and models contain the coding frequencies (f) and the corresponding percentages. In the matrices, only the coding frequencies (f) and participant comments are provided. Because the sample is relatively large for a qualitative research study, the data is presented alongside the supporting information of the participants' code and educational program.

\subsection{Findings Concerning the Effects of the Implemented PjBL Process}

The first research problem of the study asks, what are the experiences and views of PSTs concerning how the PjBL process affected them? Findings related to this research question are presented in Table 4. As shown in Table 4, a total of 507 opinions concerning the effects of the implemented PjBL process were coded. Most students' opinions concerning the PjBL process and how it affected them were positive ( $\mathrm{f}=486,95.86 \%)$. The negative opinions, captured in the response that the PjBL process didn't contribute to students' learning, were very low ( $\mathrm{f}=21,4.14 \%)$. In detail, students' responses included the codes helped them learn web design ( $\mathrm{f}=140$, $27.61 \%)$, helped them gain cooperation skills $(\mathrm{f}=75,14.79 \%)$, helped them integrate theoretical information with practice $(\mathrm{f}=64,12.62 \%)$, helped them develop professionally $(\mathrm{f}=42,8.28 \%)$, helped them learn CBE methods $(\mathrm{f}=34,6.71 \%)$, helped them gain time-management skills $(\mathrm{f}=29,5.72 \%)$, helped them learn new things $(\mathrm{f}=26$, $5.13 \%)$, helped them learn research skills $(\mathrm{f}=21,4.14 \%)$, and helped permanent learning $(\mathrm{f}=19,3.75 \%)$. The codes under the negative theme were didn't help, because the scope of the project work was too broad ( $\mathrm{f}=9$, $1.78 \%)$, didn't help, because the project was not meaningful ( $\mathrm{f}=6,1.18 \%)$, didn't help, because there was not enough time to complete the project $(\mathrm{f}=5,0.99 \%)$, and didn't help, because the project process was very painful $(\mathrm{f}=1,0.2 \%)$.

Table 4. Findings about the contribution of the implemented PjBL process

\begin{tabular}{|c|c|c|c|}
\hline Sub-theme Code & $\mathrm{F}$ & $\%$ & Statements \\
\hline Positive & 486 & 95.86 & \\
\hline Helped them learn web design & 140 & 27.61 & \multirow{6}{*}{$\begin{array}{l}\text { I think that the project contributed to my learning concerning } \\
\text { web site design and developing content. (k16, SE) } \\
\text { This project helped me learn doing work in a planned way } \\
\text { and developed my time-management skills and increased my } \\
\text { responsibility. }(k 26, S E)\end{array}$} \\
\hline Helped gain cooperation skills & 75 & 14.79 & \\
\hline Helped integrate theoretical information with practice & 64 & 12.62 & \\
\hline Helped professional development & 42 & 8.28 & \\
\hline Helped learn CBI methods & 34 & 6.71 & \\
\hline Helped gain time-management skills & 29 & 5.72 & \\
\hline Helped learn new things & 26 & 5.13 & \multirow{4}{*}{$\begin{array}{l}\text { The project was necessary as we live in the Internet age and a } \\
\text { teacher should prepare interesting materials and should use } \\
\text { different instructional strategies for teaching. }(k 102, E L T) \\
\text { We learnt not to give up easily and work patiently through the } \\
\text { project process. }(k 137, M E)\end{array}$} \\
\hline Helped learn research skills & 21 & 4.14 & \\
\hline Helped permanent learning & 19 & 3.75 & \\
\hline $\begin{array}{l}\text { Others (improved responsibility skills, taught how to work } \\
\text { patiently, taught to work according to a plan, taught the } \\
\text { importance of carefully choosing teammates, increased } \\
\text { self-confidence) }\end{array}$ & 36 & 7.1 & \\
\hline Negative & 21 & 4.14 & \\
\hline The scope of the project work was too broad. & 9 & 1.78 & It can be said that the project was necessary but if I were the \\
\hline The project was not meaningful. & 6 & 1.18 & instructor $I$ would not assign such a broad and \\
\hline There was not enough time to complete the project. & 5 & 0.99 & comprehensive project. (k279, PCG) \\
\hline The project process didn't help, because it was very painful. & 1 & 0.2 & $\begin{array}{l}\text { The time was very limited for such a project. Doing too many } \\
\text { tasks in such a limited time was very tiring. (k404,PE) }\end{array}$ \\
\hline
\end{tabular}

\subsection{Findings Concerning the Improvement of the PjBL Process}

The second research problem of the study asks what are the experiences and views of PSTs towards improving the PjBL process. As presented in Table 5, a total of 496 opinions concerning the improvement of the PjBL process were coded. 
Table 5. Findings concerning the improvement of the PjBL process

\begin{tabular}{|c|c|c|c|}
\hline Sub-theme & $\mathrm{f}$ & $\%$ & Statements \\
\hline $\begin{array}{l}\text { A similar project process but with some slightly } \\
\text { different strategies would be best. }\end{array}$ & 254 & 51.20 & $\begin{array}{l}\text { It was a very necessary project. I would do the same implementation } \\
\text { strategy, too. I would add some evaluation methods that reveal each } \\
\text { individual's contribution to the project. (k11, SE) } \\
\text { I would implement the same project but a lighter version of it. Students } \\
\text { already have some other homework and ... have too much work including } \\
\text { examinations. Therefore, I would assign a simpler project. (k115, ELT) } \\
\text { I think that in order to practice the subject assigning a project is a good } \\
\text { strategy. In this way, we were able to see that we could develop a web site. } \\
\text { I would give much more time. I would not do direct grading and I would } \\
\text { give study time for } 2 \text { weeks before I graded it. (k126, ME) }\end{array}$ \\
\hline The same project process would be best. & 159 & 32.07 & $\begin{array}{l}\text { It was not a very difficult project. We didn't do it very professionally but we } \\
\text { did our best. Without this project I wouldn't have understood how to } \\
\text { develop a web site. If I were the instructor, I would give the same project } \\
\text { and did the same things. }(\mathrm{k} 376, \mathrm{PE})\end{array}$ \\
\hline There was no need for the project. & 52 & 10.48 & $\begin{array}{l}\text { I don't think that the project was necessary because in my professional } \\
\text { teaching career I'm not going to develop a web site. }(\mathrm{k} 141, \mathrm{ME}) \\
\text { I believe that the project was not very critical. It will not contribute to my } \\
\text { teaching profession. }(\mathrm{k} 342, \mathrm{PE})\end{array}$ \\
\hline The project made no difference. & 31 & 6.25 & $\begin{array}{l}\text { Indeed, I'm not sure whether the project made a difference or not? }(k 22 \text {, } \\
\text { SE) }\end{array}$ \\
\hline
\end{tabular}

Some students' opinions were coded under the sub-theme $A$ similar project process but with some slightly different strategies would be best (I would also organize a similar project process but I would ...) $(\mathrm{f}=254,51.20 \%)$ and also some students' opinions were coded under the sub-theme The same project process would be best (I would also organize and assign nearly the same project) $(\mathrm{f}=159,32.07 \%)$. According to this sub-theme it can be said that quite a lot of PSTs are pleased with the existing project process, and it should be observed that those PSTs didn't indicate anything about improving the project process. The PSTs who were pleased with the project process but had some suggestions for a better project process were coded under the theme $A$ similar project process but with some slightly different strategies would be best $(\mathrm{f}=254,51.20 \%)$. There are a total of 17 coded opinions under this sub-theme. The most coded opinions were giving more time ( $\mathrm{f}=87,17.54 \%$ ), assigning a relatively simple project $(\mathrm{f}=29,5.85 \%)$, providing better guidance $(\mathrm{f}=22,4.43 \%)$, letting students choose to study individually or as a group ( $\mathrm{f}=17,3.43 \%$ ), changing the evaluation methods ( $\mathrm{f}=17,3.43 \%$ ), showing more examples for each project theme $(\mathrm{f}=13,2.62 \%)$, making the assignment more detailed $(\mathrm{f}=13,2.62 \%)$, reducing the number of project reports requested $(\mathrm{f}=12,2.42 \%)$, offering more flexibility in the choice of project themes $(\mathrm{f}=10,2.02)$, adding some parameters to evaluation methods to determine the contribution of each member to the project $(\mathrm{f}=6,1.21 \%)$, and other opinions which were coded four and less than four $\left(\mathrm{f}_{\text {Total }}=28,5.63 \%\right)$.

Fewer students' opinions were coded under the themes There was no need for the project (the project process was unnecessary) ( $\mathrm{f}=52,10.48 \%$ ) and The project process made no difference (There was no difference between assigning a project and not assigning it.) $(\mathrm{f}=31,6.25 \%)$. According to Table 5 , the project made no difference theme has significantly lower frequency $(\mathrm{f}=31,6.25 \%)$ than the others. These opinions can be classified as neither positive nor negative. The opinions claiming that the project was totally unnecessary were coded under the There was no need for the project theme $(\mathrm{f}=52,10.48 \%)$ and the opinions were coded under this theme can be classified as negative. The most coded opinions in this theme were The project study was not necessary for our educational program $(\mathrm{f}=25,5.03 \%)$, The project was difficult because it was a long-term project $(\mathrm{f}=5$, $1.01 \%$ ), and I'm not sure how to use the information (gained through project) in real life ( $\mathrm{f}=5,1.01 \%)$, The project was not available (or usable) $(\mathrm{f}=5,1.01 \%)$, and The project was not suitable for the level of qualification of the students $(\mathrm{f}=5,1.01 \%)$. Other opinions were coded three times or fewer $\left(\mathrm{f}_{\text {Total }}=7,1.41 \%\right)$.

\subsection{Findings Concerning the Problems Faced and Strategies for Overcoming these Problems}

Table 6 presents the data for the third research problem: problems PSTs faced during the project process and the strategies applied to overcome these problems. The data is presented as a matrix table, where rows present the problems PSTs faced and columns present the strategies and solutions for overcoming the corresponding problems. Thus, every intersecting cell provides information about a problem PSTs faced and the strategy and 
the solution for overcoming it. While reading the table it must be taken into consideration that a problem can have more than one solution and a given solution might be used for more than one problem.

Table 6. The problems PSTs faced and strategies for overcoming these problems

\begin{tabular}{lcccc}
\hline & $\begin{array}{c}\text { Internet } \\
\text { research } \\
(\mathrm{f}=168)\end{array}$ & $\begin{array}{c}\text { Working hard } \\
\text { until finding a } \\
\text { solution } \\
(\mathrm{f}=100)\end{array}$ & $\begin{array}{c}\text { Exchanging } \\
\text { ideas with } \\
\text { members } \\
(\mathrm{f}=79)\end{array}$ & $\begin{array}{c}\text { Requesting } \\
\text { instructor } \\
\text { guidance } \\
(\mathrm{f}=72)\end{array}$ \\
\hline Coding problems (writing the code, the code doesn't run & 75 & 54 & 28 & 31 \\
as expected) (f=150) & 49 & 30 & 22 & 17 \\
Not being able to find content (f=97) & 35 & 20 & 22 & 12 \\
Problems meeting with group members (f=94) & 44 & 33 & 28 & 18 \\
Problems with the design process (f=91) & 18 & 11 & 4 & 3 \\
Timing problems (f=39) & 16 & 10 & 7 & 8 \\
Not being able to understand the project $(\mathrm{f}=36)$ & 17 & 10 & 8 & 9 \\
Problems preparing project reports (f=34) & & & & \\
\hline
\end{tabular}

As Table 6 shows, the first of three main problems PSTs faced were coding problems (writing, not working) $(\mathrm{f}=150)$ during design and development processes of the project. For example, two different students from the English Language Teaching program expressed similar sentiments:

"I had difficulty in placing pictures to where I wanted to place. I tried so much but eventually I was able to overcome this problem. After working for hours I was happy because I was able to do what I wanted. I felt the web site we developed was like my baby." (k113, ELT)

"I had difficulties in developing processes, especially coding html. Indeed, I spent very limited time for this course and the project." (k117, ELT)

The second-most frequently expressed problem was Not being able to find content ( $f=97)$. The PSTs were expected to choose appropriate topics for their project themes. Finding appropriate content for their topic was problematic, according to PSTs. For example, a female PST from the English Language Teaching program (k111) stated,

"At the beginning we had difficulties in finding some simulations. Eventually, we found a web site that included many of them. After finding those, our project work went very well." (k111, ELT)

Another PST (k410) from the Primary School Education program underlined this:

"Sometimes we had difficulties in finding appropriate content for our learning gains and project theme. Therefore, we had to research too much." (k410, PE)

Problems meeting with group members $(\mathrm{f}=94)$ was the third-most frequently reported problem by the PSTs. These PSTs expressed that they were not able to come together to work. A PST (k11) from the Science Education program briefly indicated,

"I was staying in downtown but my group members were staying at dormitories close to campus.

Therefore, we didn't manage to work together." (k11, SE)

It can be seen in Table 6 that Internet research $(\mathrm{f}=168)$ was the most frequently reported solution as a strategy to overcome problems. The second-most frequently reported strategy was working hard until finding a solution $(\mathrm{f}=100)$, followed by exchanging ideas with members $(\mathrm{f}=79)$ and requesting instructor guidance $(\mathrm{f}=72)$. For example, a PST from the Preschool Education program expressed,

"During the second week of the project process we had big problems concerning html coding. We spent hours for an html tag. We printed lecture notes about html and researched on the Internet. When we were not successful we went our homes. We worked on the problems individually and in the next meeting we had a final decision. Overall, we made internet search, used lecture notes and course web site." (k243, PSE)

Another problem expressed by the PSTs was not being able to find content ( $\mathrm{f}=97)$. As before, Internet research $(f=49)$ was the most frequently expressed strategy for overcoming the problem, followed by working hard until finding a solution $(\mathrm{f}=30)$. A PST from the Mathematics Education program $(\mathrm{k} 191)$ expressed, 
"Simulations are not used widely. Therefore, we had difficulties concerning finding content for the web site. We discussed with our friends, researched on the Internet and requested guidance from our instructor." (k191, ME)

In addition to the data reported in Table 6, the remaining problems reported by the PSTs were timing problems $(\mathrm{f}=39)$, not being able to understand the project $(\mathrm{f}=36)$, and problems preparing project reports $(\mathrm{f}=34)$. The strategies reported for overcoming these problems were similar to those for the aforementioned problems: Internet research, working hard until finding a solution, and requesting instructor guidance.

\subsection{Findings Concerning Resources and Research Methods Used}

For the fourth research problem, in order to reveal what resources and research methods were used, the PSTs were asked two questions: Which information sources did you use for your project? and How did you classify the information at hand and how did you use the information for your project? The findings about resources are presented in Figure 2 and the research methods are presented in Figure 3 below.

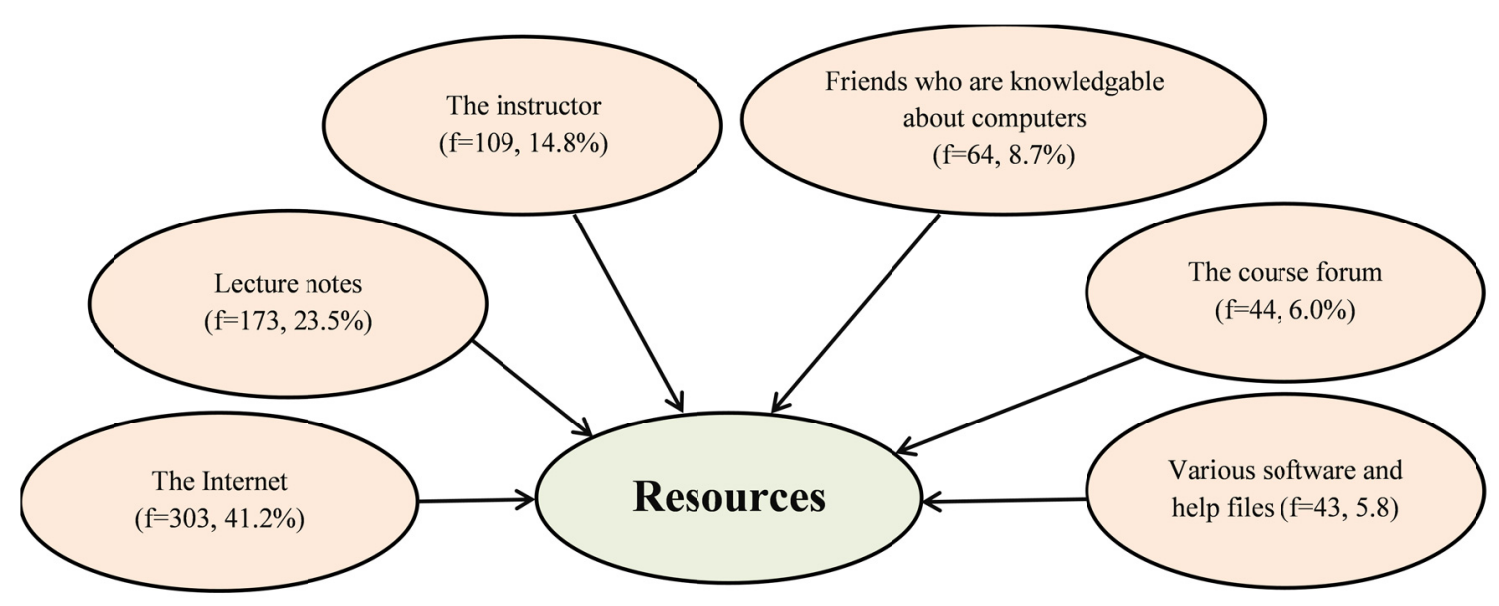

Figure 2. The resources used by the students during the project process

According to Figure 2, the most frequently used resource was the Internet ( $\mathrm{f}=303,41.2 \%)$ followed by lecture notes through the course web site $(\mathrm{f}=173,23.5 \%)$. Students communicated with the instructor face-to-face and through e-mail ( $\mathrm{f}=109,14.8 \%)$. Students also stated that they requested help from other students who had a high degree of knowledge about computers ( $\mathrm{f}=64,8.7 \%)$. Using the course forum $(\mathrm{f}=44,6.0 \%)$ and using various web design tools and software and their help files $(\mathrm{f}=43,5.8 \%)$ were the final two resources that the students utilized in terms of frequency.

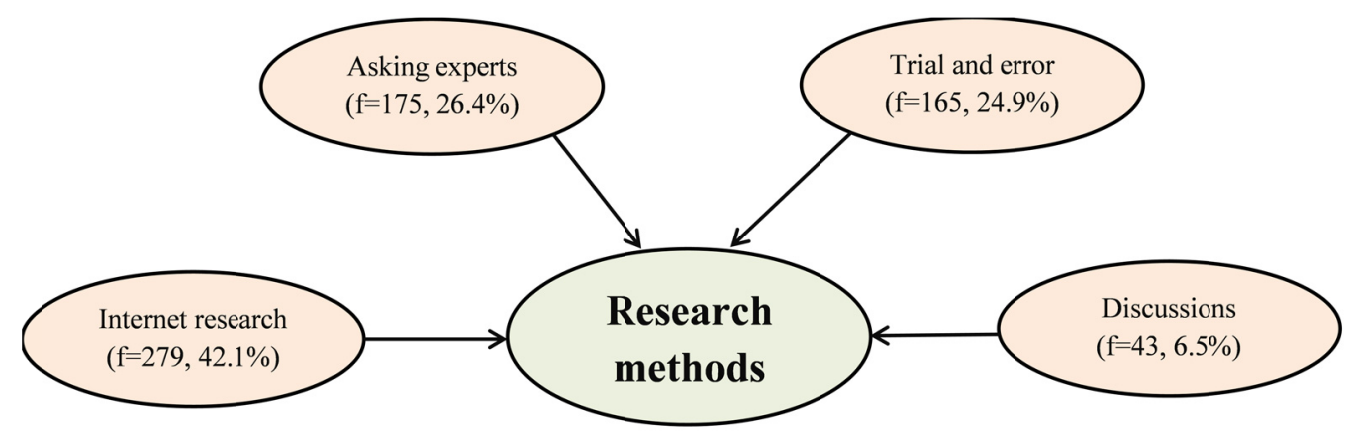

Figure 3. The research methods PSTs used

The research methods PSTs used during the project process were Internet research ( $\mathrm{f}=279,42.1 \%)$, asking 
experts $(\mathrm{f}=175,26.4 \%)$, trial and error $(\mathrm{f}=165,24.9 \%)$, and discussions $(\mathrm{f}=43,6.5 \%)$, especially within group discussions. As shown in Figure 3, most PSTs were able to overcome problems in the project process by utilizing Internet research, group discussions, and trial and error (the total of all these three was $73.5 \%$ ). In other words, PSTs were mostly able to finish the project without requesting help from other people outside of their groups. The remaining $26.4 \%$ of groups of PSTs needed the help of others to overcome some project processes. Asking an expert, who might be the instructor, another project group, or a friend from another department, can be included in that $26.4 \%$.

\subsection{Findings Concerning Preferences When Forming Groups}

The fifth research question of the study was, What are the criteria that determine PSTs' preferences when forming groups? The findings related to this research question are presented in Table 7. A total of 409 opinions concerning PSTs' preferences when forming groups were coded, under nine codes. PSTs mostly preferred to form their project groups with people they have a close friendship with $(\mathrm{f}=113,27.63 \%)$ and they reported that they also formed groups with people with whom they could easily come together and have meetings ( $\mathrm{f}=96$, $23.47 \%$ ). In other words, people who could be contacted easily were preferred when forming project groups. The third-most frequently expressed preference was for people whom were going to get along well with $(\mathrm{f}=73$, $17.85 \%)$. The remaining factors that influenced the formation of groups were for people who would take responsibility ( $\mathrm{f}=35,8.56 \%$ ), were joined with for purely circumstantial reasons $(\mathrm{f}=27,6.60 \%)$, would collaborate on equal terms $(f=25,6.11 \%)$, would complement each other's weaknesses $(f=10,2.44 \%)$, and would be able to work regularly and steadily $(f=10,2.44 \%)$. The other factors (people who have computer knowledge, have a computer, are hard-working, are interested in the course content, are at an equal level of knowledge) were coded five times or fewer $(f=20,4.89 \%)$.

Table 7. The findings concerning PSTs' preferences when forming groups

\begin{tabular}{|c|c|c|c|}
\hline Codes & $\mathrm{f}$ & $\%$ & Statements \\
\hline Close friendship & 113 & 27.63 & $\begin{array}{l}\text { We were close friends. Therefore, we came together in the same } \\
\text { group. }(k 104, E L T)\end{array}$ \\
\hline Can be contacted easily & 96 & 23.47 & $\begin{array}{l}\text { During the project studies everyone should be able to come } \\
\text { together easily so that we can have meetings easily. In other words, } \\
\text { we preferred people that can be contacted easily. (k223, PSE) }\end{array}$ \\
\hline Getting along & 73 & 17.85 & $\begin{array}{l}\text { In general, we formed our groups based on the criteria that we } \\
\text { have got along with each other. }(k 107, E L T)\end{array}$ \\
\hline Taking responsibility & 35 & 8.56 & $\begin{array}{l}\text { I preferred to work with people who can take responsibilities } \\
\text { during project. }(k 392, P E)\end{array}$ \\
\hline Circumstantial & 27 & 6.60 & $\begin{array}{l}\text { I didn't have any criteria. We determined our group members by } \\
\text { lot. }(k 232, P S E)\end{array}$ \\
\hline Equal collaboration & 25 & 6.11 & $\begin{array}{l}\text { I wanted that every member of the group should contribute equally } \\
\text { to project work. Therefore, I preferred to work with people who can } \\
\text { collaborate equally. }(k 237, \text { PSE) }\end{array}$ \\
\hline Complementing each other's weaknesses & 10 & 2.44 & $\begin{array}{l}\text { We were careful to be the ones who would complement each other's } \\
\text { missing. }(k 12, S E)\end{array}$ \\
\hline Able to work regularly and steadily & 10 & 2.44 & $\begin{array}{l}\text { I thought of choosing a regular and a stable person with computer } \\
\text { knowledge and working style. }(k 102, E L T)\end{array}$ \\
\hline $\begin{array}{l}\text { Other factors (have knowledge about computers, have a } \\
\text { computer, be hard-working, are interested in the course } \\
\text { content, be at an equal level of knowledge) }\end{array}$ & 20 & 4.89 & $\begin{array}{l}\text { I made choices based on my ability to work with my friend and } \\
\text { thinking that our knowledge levels are the same. (k23, SE) } \\
\text { I did not have a personal computer, so I made sure that at least one } \\
\text { of the group's members had a computer. (k10, SE) } \\
\text { I chose friends who can understand and have computer knowledge. } \\
\text { (k156, ME) }\end{array}$ \\
\hline
\end{tabular}

\subsection{Findings Concerning the Problems PSTs Faced While Working in Groups}

The other part of the fifth research question was, What were PSTs' difficulties when forming groups? The findings related from this part of the fifth research question are under three sub-themes and are presented in Table 8. A total of 409 opinions from PSTs about their difficulties when forming groups were coded. A few PSTs $(\mathrm{f}=28,6.86 \%)$ stated that they were fine with their group's working performance but that there were some minor 
problems. In addition, a great deal of PSTs stated that they had no problems ( $\mathrm{f}=333,81.42 \%$ ) while working in groups. The number of PSTs who reported that they had problems concerning group work was relatively very low $(\mathrm{f}=48,11.74 \%)$.

Table 8. The findings concerning the problems PSTs faced while working in groups

\begin{tabular}{|c|c|c|c|}
\hline Sub-theme/Code & $\mathrm{f}$ & $\%$ & tatements \\
\hline $\begin{array}{l}\text { Although I was very satisfied there were a few } \\
\text { unsatisfactory times }\end{array}$ & 28 & 6.86 & $\begin{array}{l}\text { was pleased with my group. There were some problems and conflicts but } \\
\text { the end I realized that I learnt too much from this process. }(k 375, P E)\end{array}$ \\
\hline Had no problems & & 81.42 & \multirow{8}{*}{$\begin{array}{l}\text { I believe that our group's performance was very good. First, we decided } \\
\text { what was going to be done together and individually. We had a common } \\
\text { decision on what was going to be done. We listened to different ideas of all } \\
\text { members and gave a final decision together. (k11, SE) } \\
\text { We didn't have problems because we divided the tasks to be done. Then } \\
\text { everyone did what was assigned to him. If a member had not been able to } \\
\text { overcome a task other members had helped. (k190, ME) } \\
\text { Individuals must be aware of their responsibilities, especially considering } \\
\text { such tough projects. I was very happy to work with my group. (k141, ME) } \\
\text { I have not lived any discussion in my group. I am satisfied. Because it was } \\
\text { an absorbing and funny project (k259, PSE) } \\
\text { We did not have a lot of problems in the group. We did not have much time } \\
\text { for collaborative work, but there was no conflict. ( } k 302, \text { PCG) } \\
\text { I was pleased with the work performance of the group, because I enjoyed } \\
\text { working long hours (k151, ME) }\end{array}$} \\
\hline $\begin{array}{l}\text { because we reached decisions together and } \\
\text { worked together }\end{array}$ & 107 & 26.16 & \\
\hline because we made a fair division of labor & 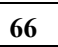 & 16.13 & \\
\hline becau & & & \\
\hline because everyone contributed & & & \\
\hline because we respected each other's ideas & 26 & & \\
\hline Our friendship relations were good. & & & \\
\hline $\begin{array}{l}\text { Others (didn't undertake collaborative work but } \\
\text { it wasn't a problem, project was absorbing, } \\
\text { enjoyed working long hours demanded by an } \\
\text { absorbing project) }\end{array}$ & 19 & 4.65 & \\
\hline $\mathrm{Had} \mathrm{p}$ & & & \\
\hline $\begin{array}{l}\text { because at least one group member didn't } \\
\text { contribute to the study }\end{array}$ & 20 & 4.89 & \multirow{3}{*}{$\begin{array}{l}\text { Division of labor was not fair and there were some problems. The reason } \\
\text { for having problems was that one group member didn't do his tasks. I did } \\
\text { all the work instead of him! (k109, ELT) } \\
\text { This is not about friendship but I wish we had some common points } \\
\text { concerning the project. We were not able to find a common ground for } \\
\text { doing the project. It would have been different if we had been more } \\
\text { determined. (k309, PCG) } \\
\text { Everyone had different ideas, but I cannot say much what we did. We were } \\
\text { forced to come in together. }(k 256, P S E)\end{array}$} \\
\hline $\begin{array}{l}\text { because group members were not able to find a } \\
\text { common ground }\end{array}$ & 18 & 4.4 & \\
\hline because members had trouble getting together & 10 & 2.45 & \\
\hline
\end{tabular}

According to Table 8, the most popular explanations for those who had no problems during group work were because we reached decisions together and worked together ( $\mathrm{f}=107,26.16 \%)$, because we made a fair division of labor $(\mathrm{f}=66,16.13 \%)$, and because everyone took responsibilities $(\mathrm{f}=63,15.4 \%)$. On the other hand, when the reasons why PSTs had problems while working in groups are investigated, the following opinions were coded: because at least one group member didn't contribute to the study ( $\mathrm{f}=20,4.89 \%)$, because group members were not able to find a common ground $(\mathrm{f}=18,4.4 \%)$, and because there was trouble coming together $(\mathrm{f}=10,2.45 \%)$.

3.7 Findings Concerning the Relationship between PSTs' Preferences When Forming Groups and Problems They Faced While Working in Groups

Table 9 below presents a matrix with information about the sixth research problem: PSTs' preferences when forming groups and the problems they faced while working in groups. The columns present the codes for problems faced within group work. The rows present the codes for preferences when forming groups. 
Table 9. The findings concerning the relationship between PSTs' preferences when forming groups and problems they faced while working in groups

\begin{tabular}{|c|c|c|c|c|c|c|c|}
\hline & $\begin{array}{c}\text { Close } \\
\text { friendship } \\
(\mathrm{f}=113)\end{array}$ & $\begin{array}{c}\text { Could be } \\
\text { contacted } \\
\text { easily } \\
(\mathrm{f}=96)\end{array}$ & $\begin{array}{l}\text { Got } \\
\text { along } \\
(\mathrm{f}=73)\end{array}$ & $\begin{array}{l}\text { Took } \\
\text { responsibility } \\
(\mathrm{f}=35)\end{array}$ & $\begin{array}{l}\text { Circumsta } \\
\text { ntial } \\
(\mathrm{f}=27)\end{array}$ & $\begin{array}{c}\text { Equal } \\
\text { collaboration } \\
(\mathrm{f}=25)\end{array}$ & $\begin{array}{l}\text { Others } \\
(\mathrm{f}=40)\end{array}$ \\
\hline $\begin{array}{l}\text { Fine but there were some minor } \\
\text { problems }(f=28)\end{array}$ & 6 & 9 & 5 & 0 & 2 & 1 & 5 \\
\hline $\begin{array}{l}\text { Had problems/because at least one group } \\
\text { member didn't contribute to the study } \\
(\mathrm{f}=20)\end{array}$ & 12 & 4 & 0 & 1 & 1 & 1 & 1 \\
\hline $\begin{array}{l}\text { Had problems/because group members } \\
\text { were not able to find a common ground } \\
(\mathrm{f}=18)\end{array}$ & 4 & 4 & 4 & 3 & 2 & 0 & 1 \\
\hline $\begin{array}{l}\text { Had problems/because they had trouble } \\
\text { coming together }(\mathrm{f}=10)\end{array}$ & 4 & 0 & 0 & 0 & 3 & 3 & 0 \\
\hline $\begin{array}{l}\text { Had no problems/because we reached } \\
\text { decisions together and worked together } \\
(\mathrm{f}=107)\end{array}$ & 29 & 27 & 29 & 6 & 0 & 5 & 11 \\
\hline $\begin{array}{l}\text { Had no problems/because we made a } \\
\text { fair division of labor }(\mathrm{f}=66)\end{array}$ & 13 & 16 & 12 & 11 & 0 & 5 & 9 \\
\hline $\begin{array}{l}\text { Had no problems } / \text { because everyone took } \\
\text { responsibility }(\mathrm{f}=63 \text { ) }\end{array}$ & 12 & 14 & 8 & 11 & 6 & 6 & 6 \\
\hline $\begin{array}{l}\text { Had no problems/because everyone } \\
\text { contributed }(\mathrm{f}=28)\end{array}$ & 5 & 5 & 9 & 2 & 2 & 1 & 4 \\
\hline $\begin{array}{l}\text { Had no problems/because we respected } \\
\text { each other's ideas }(\mathrm{f}=26)\end{array}$ & 6 & 9 & 6 & 1 & 0 & 3 & 1 \\
\hline $\begin{array}{l}\text { Had no problems } / \text { because our } \\
\text { friendships were } \operatorname{good}(\mathrm{f}=24)\end{array}$ & 14 & 5 & 0 & 0 & 4 & 0 & 1 \\
\hline $\begin{array}{l}\text { Had no problems/for other reasons } \\
(\mathrm{f}=19)\end{array}$ & 8 & 3 & 0 & 0 & 7 & 0 & 1 \\
\hline
\end{tabular}

In Table 9, the other reasons ( $\mathrm{f}=40$ ) option includes codes about group preferences such as we complemented each other's weaknesses, we were able to work regularly and steadily, we had people who were knowledgeable about computers, we had at least one person with a computer, we had people who were hard-working, we had people who were interested in the course content, and we were equally knowledgeable. These are grouped under the other reasons option because they are not mentioned in PSTs' statements about the problems they encountered. According to the Table 9, PSTs rarely indicated whether they faced problems concerning group work based on their group forming preferences. Therefore, it can be said that PSTs were successful in forming groups and tended to not have too many problems based on their groups. Most PSTs' statements are coded under the had no problems theme. For example, for PSTs who formed their groups based on close friendships ( $f=113)$, when asked whether they had faced problems or not, most of them indicated that they didn't face problems because at least one of the following was true: they reached decisions together and worked together $(\mathrm{f}=29)$, they had good friendships $(\mathrm{f}=14)$, they made a fair division of labor $(\mathrm{f}=13)$, or they had responsibility $(\mathrm{f}=12)$. For example a PST from the Psychological Counselling and Guidance program stated,

"The reason why I joined this group is to be together with my friends with whom I get along. I was pleased to work with my friends. Everyone did his/her job. We sometimes had disagreements but we listened to each other and we were able to find a common ground to move on.” (k281, PCG)

A PST in the Mathematics Education program underlined the importance of knowing the group members:

"I tried to form a group with people with whom I can get along and who are conformist. We were able to do all of the project work together. When we had problems, everyone stated his/her ideas and the most appropriate solution were selected as the group choice. We didn't have too many conflicts during the project processes." (k182, ME)

For the groups that formed based on the preference for close friendships, few PSTs indicated that they had 
problems within their groups. The most frequently made statement was we had problems because at least one group member didn't contribute to the study $(\mathrm{f}=12)$. For example, a PST from the Science Education program clearly stated,

"We formed our group based on the criteria that we were close friends and sincere. We tried to be responsible persons. We were 3 persons in the group but actually 2 of us did all the work. The other member of our group did not contribute to most of the tasks (especially design and development tasks of the project). Considering this situation, we completed the project as 2 people. Therefore, we submitted our project late." (k399, SE)

Another PST in the Primary Education program (k400) indicated,

"I formed my group with my buddies. But, now I realized that I was wrong because, I did most of the project work myself. They didn't help me at all." (k400, PE)

For the PSTs whose answers to the question about whether they encountered problems was fine but there were some minor problems $(f=28)$, their preferences when forming groups were based on close friendships $(\mathrm{f}=6)$, who could be contacted easily $(\mathrm{f}=9)$, and who they could get along with $(\mathrm{f}=5)$. A PST in the Primary Education program indicated,

"We formed our group as three male students. I was glad to work with one but the other didn't contribute. We really had time-management problems. We had limited time but a lot of work to do. I didn't contribute enough, either." (k414, PE)

The PSTs who had problems with their group members during their project stated the following:

"It was circumstantially. I was not pleased with my group. We didn't make a good division of labor" (k373, PE) and

"I was absent that day. Some others included me in their groups, they had chosen me. I don't like group studies. I would be very comfortable if the course required individual work. Because, I don't trust anyone's work." (k353, PE)

Finally, another PST in the Primary Education program (k377) whose response was that they had no problems expressed,

"The week that I was absent, our teacher required students to form groups for the project work. I was included with my friends in their group. I was pleased to work with them. We worked together and we didn't have any problems during group work." (k377, PE)

\section{Conclusion and Discussion}

The aim of this study was to examine PSTs' experiences with group work and collaboration, the resources and research methods they used, and how their academic development was affected by project-based learning (PjBL) processes. The PjBL process was based on information and communication technology (ICT) and group work. ICT was used not only to learn about technology but also to learn with technology. In addition, the study investigated how PSTs participating in a PjBL process formed groups and undertook group work, how they used ICT, and what their opinions were regarding the technology. The conclusions based on the results of 413 PSTs from various educational programs are presented and discussed below.

The first research problem concerns how the PjBL process affected the PSTs. The context of this study was the course Computer 2, which is focused on computer-based instruction (CBI) methods (like educational software) and their characteristic features. In this ICT-integrated course, PSTs study the theoretical basis of CBI methods as well as the basics of web design and undertake a project to produce a simple piece of educational software by using theoretical knowledge about CBI and web design. In considering the answer to the first research problem, it can be stated that the PjBL process as implemented contributed to PSTs' satisfaction with their academic learning, increased their theoretical knowledge, and enabled them to put their knowledge into practice (Edwards \& Hammer, 2006). The PSTs stated that the PjBL process especially helped them learn basic web design and CBI methods (e.g., simulation, educational games, and tutorials). These findings support the existing research into how the PjBL process affects students' academic achievement and the success of the course (Özer \& Özkan, 2013; Peck, Peck, Sentz, \& Zasa, 1998). Additionally, PSTs perceived that the PjBL process increased their academic skills, including researching (Chan Lin, 2008), working in groups (Lary, Lavigne, Muma, Jones, \& Hoef, 1997), time management, and having professional responsibility.

The second research problem investigated the overall PjBL process. Most PSTs stated that they would also implement a similar PjBL environment and would not add anything to the PjBL process as implemented, and 
many others indicated that they would also implement a PjBL process but would make some minor changes. These statements clearly indicate that PSTs believe that the PjBL environment supported their learning processes and that they gained some skills from the process. PSTs also provided some suggestions for improving the PjBL processes. They stated that the time allocated for the project, which was five weeks, should be increased, indicating that some PSTs had time-management problems (Krajcik, Blumenfeld, Marx, Bass, Fredricks, \& Soloway, 1998). In addition, some PSTs thought that the project was unrelated to their profession and therefore that the PjBL process was unnecessary. This result supports the discussion that teacher beliefs are a determinant in whether technology is used for learning and classroom instruction (Hermans, Tondeur, van Braak \& Valcke, 2008). This response might indicate that these PSTs believe that both in daily life and in their future teaching lives they would not use technology too much. Yavuz and Coşkun (2008) found that some PSTs had positive attitudes towards the utilization of ICT in education. On the other hand, Shi et al. (2004) asserted in their work that many PSTs or teachers perceived the use of ICT as inessential in content learning. However, they also claimed that the role of technology as an important component of knowledge construction and the influence of PSTs'/teachers' beliefs in integrating ICT into content learning are two important issues for technology integration in the field of education. Considering that the participants of this study were freshmen, such a result, which underestimates the role of the technology in educational environments, may be common. Considering the results of this study and those of the study by Shi et al. (2004), it can be concluded that there is a need for more studies to explore how technology-based learning activities can enhance PSTs' professional development.

The third research problem of this study concerned the problems PSTs faced during the PjBL processes and the strategies they used to overcome these problems. The PSTs' project was to develop an educational web site. The students were assigned project themes (e.g., tutorial, drill and practice, educational game), but they were required to decide for themselves the topic and content they were going to include in their web sites. The first-ranked problem was in using ICT while developing their projects. The second-most common problem was difficulty finding appropriate content for the project themes. Donnelly and Fitzmaurice (2005) asserted in their study that it is important for students to avoid wasting time tracking down obscure resources for their projects and that students should be encouraged to request resources related to the project themes from the instructor. In this study, the PSTs were freshmen and this was their first PjBL experience in terms of using technology. In this study PSTs mostly utilized Internet research in order to solve their problems. This finding is also supported by the following findings about the resources and research methods the PSTs used.

The fourth research problem concerned which resources and research methods the PSTs used. The findings show that PSTs mostly used the Internet, the instructor, and lecture notes as resources. It is worth noting that relatively few students sought help from outside people who were known to have computer knowledge. It can be concluded that PSTs were able to navigate the PjBL process mostly by utilizing the available course resources and the Internet. The Internet was the main research resource, which is an important point, because the course aims to increase PSTs' problem-solving skills and research skills via the integration of ICT. The instructor and course materials were used as additional resources, which may indicate that the communication strategy between the instructors and the PSTs was well organized. In addition, the checkpoints within the whole PjBL process helped both the instructors and PSTs to track progress. Some studies have claimed that when complex projects are laid out in phases with accessible milestones, thus helping reducing project complexity, students can enhance their project-development processes and enrich their own learning processes (Karaman \& Çelik, 2008; Koh, Herring \& Hew, 2010). Thus, PjBL environments should have detailed structures and offer the necessary scaffolding for the development of PSTs' skills.

Given the results of our investigation into the four research problems discussed above, we suggest that the PjBL environment supports PSTs' learning and develops their skills, such as researching and collaboration, as well as their responsibility. Therefore, teacher-training programs should have courses designed with constructivist learning approaches and student-centered teaching methods (like PjBL) in order to help PSTs become successful practitioners of PjBL.

In their 2016 study, Chang and Lee asserted that teachers are the key to enhancing students' practical knowledge and abilities. Teachers should support their students' ability to transfer what they learned in school to real life. Thus, teachers should design more PjBL environments (Chang \& Lee, 2016). To achieve this, courses that integrate pedagogy, technology, and content knowledge should be included in all aspects of teacher education programs (Tondeur, Pareja Roblin, van Braak, Voogt, \& Prestridge, 2016) and such courses should provide opportunities for PSTs to experience various learning strategies, such as PjBL (Lavy \& Shriki, 2008).

The fifth and sixth research problems investigated PSTs' group work and related factors concerning the PjBL environment. Group-based learning provides a situation in which students can effectively gain, practice, and 
improve certain skills, such as communication and conflict resolution (Cheong, 2010). In group-based learning, groups can be formed in various ways in relation to course structure, and it is suggested that each group be limited to fewer than seven members (Cheong, 2010). In our study, groups were formed according to PSTs' own preferences and group size was limited to be no more than four members. PSTs mostly preferred to work with people with whom they were close friends, people they believed they would get along with, and people who could be contacted easily. Based on these findings, it can be concluded that PSTs want to collaborate with people they can easily meet up with for joint work and meetings (Borg, Kembro, Notander, Petersson, \& Ohlsson, 2011). Pinho-Lopes and Macedo (2016) claimed that students prefer teamwork to the alternative because it decreases the responsibility and workload of each individual. On the other hand, in our study PSTs accepted collaboration because they freely choose their group members and had the opportunity to come together. Takeuchi (2016) explains that group work offers a collective space in which students learn and develop together while they solve a task and think collectively. In addition, Springer, Stanne, and Donovan (1999) suggested that the more time students spend working groups, the better their learning-related attitudes.

Based on the results concerning PSTs' group work and related factors concerning the PjBL environment, we would suggest that PSTs be given the opportunity to choose their group members according to their preferences. Our results also show that when PSTs determine their groups, they are able to solve the problems they face more easily because they have close friendships, can contact with each other more easily, and they get along better. PSTs overall reported that because they worked together, had a fair division of labor, and all took responsibilities, they didn't have problems while working in groups. However, there were a few groups that did report problems concerning group work. These groups were mostly the ones that weren't able to form groups based on close friendship and factors that would make communication easy.

As a result, the following suggestions are offered to help researchers and instructors design effective PjBL environments. PjBL environments support PSTs' learning and their research and collaboration skills while also increasing their responsibility. In addition, PjBL environments help PSTs learn how to implement constructivist learning approaches and student-centered teaching. Therefore teacher education programs should have courses that utilize PjBL processes. PjBL environments should be designed to have phases and checkpoints, and these checkpoints should provide the scaffolding designed to promote the development of PSTs' research and collaboration skills. In PjBL processes, checkpoints should be set to enable the monitoring of PSTs' progress during the process, and the checkpoints should help examine the ways PSTs are collaborating. Finally, PSTs should be free to choose group members. Allowing PSTs to determine their group members decreases the possibility of problems during group work and increases the likelihood of solving the problems that arise.

\section{Limitations of the Study}

This study was limited because it considered only one semester course and because the participants of the study were freshmen. We also cannot know how PSTs' views may change depending on their future experiences with PjBL. Group-based learning had a positive effect on the PjBL process, and we saw that it was possible for PSTs to successfully carry out their projects if they communicated well within their groups. But, we do not know anything about the communication between groups nor about the impact of such communication on the project processes.

This study investigated PSTs' experiences with and views on PjBL processes. The impact of some factors such as motivation and communication skills on academic achievement concerning group work-based PjBL processes is one possible area for further research. Additionally, observational studies could be designed to investigate actual group dynamics in PjBL environments as well as the effects of within-group and between-group communication on $\mathrm{PjBL}$ processes.

\section{References}

Abdulwahed, M., Nagy, Z. K., \& Blanchard, R. E. (2008). Constructivist project based learning design, a cybernetics approach. In F. Malpica et al. (Eds.), Proceedings of the 2nd International Multi-Conference on Society, Cybernetics and Informatics (pp. 119-126). Orlando, USA: International Institute of Informatics and Systemics.

Amiel, T., \& Reeves, T. C. (2008). Design-based research and educational technology: Rethinking technology and the research agenda. Educational Technology \& Society, 11(4), 29-40.

Arends, R. I. (2012). Learning to teach. New York: McGraw-Hill.

Bagley, C., \& Hunter, B. (1992). Restructuring constructivism and technology: Forging a new relationship. Educational Technology, 32(7), 22-27. 
Bellanca, J. \& Brandt, R. (Eds.). (2010). $21^{\text {st }}$ century skills: Rethinking how students learn. Bloomington, IN: Solution Tree.

Borg, M., Kembro, J., Notander, J. P., Petersson, C., \& Ohlsson, L. (2011). Conflict management in student groups - A teacher's perspective in higher education. Hogre Utbildning, 1(2), 111-124. Retrieved from http://journals.lub.lu.se/index.php/hus/article/view/4923/4687

Brickman, L., \& Debra J. R., (1998). Handbook of applied social research methods. Thousand Oaks, CA: Sage Publications.

Cavanaugh, C. (2004). Project-based learning in undergraduate educational technology. In R. Ferdig et al. (Eds.), Proceedings of Society for Information Technology \& Teacher Education International Conference 2004 (pp. 2010-2016). Chesapeake, VA: AACE.

Chang, L. C., \& Lee, G. C. (2010). A team-teaching model for practicing project-based learning in high school: Collaboration between computer and subject teachers. Computers \& Education, 55(3), 961-969. https://doi.org/10.1016/j.compedu.2010.04.007

ChanLin, L. J. (2008). Technology integration applied to project-based learning in science. Innovations in Education and Teaching International, 45(1), 55-65. https://doi.org/10.1080/14703290701757450

Cheng, W. Y., Lam, S. F., \& Chan, C. Y. (2008). When high achievers and low achievers work in the same group: The roles of group heterogeneity and processes in project-based learning. British Journal of Educational Psychology, 78(2), 205-221. https://doi.org/10.1348/000709907X218160

Cheong, C. (2010). From group-based learning to cooperative learning: A metacognitive approach to project-based group supervision. Informing Science: The International Journal of an Emerging Transdiscipline, 13(1), 73-86.

Ching, Y. H., \& Hsu, Y. C. (2013). Peer feedback to facilitate project-based learning in an online environment. The International Review of Research in Open and Distributed Learning, 14(5). https://doi.org/10.19173/irrodl.v14i5.1524

Collins, A., \& Halverson, R. (2009). Rethinking education in the age of technology: The digital revolution and schooling in America. New York: Teachers College Press.

Cunha, P. R. (2005). Teaching software engineering using project-based learning. Paper presented at International Conference on Engineering Education and Research, Tainan, Taiwan, ROC. Abstract retrieved from https://www.cisuc.uc.pt/publication/show/867.

Dağ, F., \& Durdu, L. (2012). Öğretmen adaylarının proje tabanlı öğrenme sürecine yönelik görüşleri. e-Journal of New World Sciences Academy-Education Sciences, 7(1), 200-211.

De Los Rios, I., Cazorla, A., Díaz-Puente, J. M., \& Yagüe, J. L. (2010). Project-based learning in engineering higher education: Two decades of teaching competences in real environments. Procedia-Social and Behavioral Sciences, 2(2), 1368-1378. https://doi.org/10.1016/j.sbspro.2010.03.202

Demirel, Ö. (2007). Eğitimde program geliştirme [Curriculum development in education]. Ankara: Pegem A Yayıncilik.

Demirhan, C. (2002). Program geliştirmede proje tabanlı öğrenme yaklaşımı [Project-based learning in curriculum development] (Unpublished master's thesis). Hacettepe University Graduate School of Science and Engineering, Ankara.

Diffily, D. (2002). Project-based learning: Meeting social studies standards and the needs of gifted learners. Gifted Children Today Magazine, 25, 40-40. https://doi.org/10.4219/gct-2002-69

Donnelly, R., \& Fitzmaurice, M. (2005). Collaborative project-based learning and problem-based learning in higher education: Consideration of tutor and student roles in learner-focused strategies. In G. O. Neill, S. Moore, \& B. McMulling,(Eds.), Emerging Issues in the Practice of University Learning and Teaching (pp. 87-98). Dublin: All Ireland Society for Higher Education (AISHE).

Edutopia. (2016). Project-based learning. Retrieved from http://www.edutopia.org/project-based-learning.

Edwards, S., \& Hammer, M. (2006). Laura's story: Using problem based learning in early childhood and primary teacher education. Teaching and Teacher Education, 22(4), 465-477. https://doi.org/10.1016/j.tate.2005.11.010

Erdem, M. (2002). Project based learning. Hacettepe University Journal of Education, 22, 172-179. 
Erdem, M., \& Akkoyunlu, B. (2002). İlkögretim sosyal bilgiler dersi kapsamında beşinci sınıf ögrencileriyle yürütülen ekiple proje tabanlı öğrenme üzerine bir çalışma [A study with fifth grade-students taking the social sciences course at primary level about project-based learning]. Illkögretim-Online, 1(1), 2-11.

Fox-Turnbull, W., \& Snape, P. (2011). Technology teacher education through a constructivist approach. Design and Technology Education: An International Journal, 16(2), 45-56.

Hancock, B., Ockleford, E., \& Windridge, K. (2009). An introduction to qualitative research. Yorkshire: The NIHR RDS.

Haney, W., Russell, M., Gulek, C., \& Fierros, E. (1998). Drawing on education: Using student drawings to promote middle school improvement. Schools in the Middle, 7(3), 38-43.

Hannafin, M. J., Land, S. M., \& Oliver, K. (1997). Grounded practice and the design of constructivist learning environments. Educational Technology Research and Development, 45(3), 101-117. https://doi.org/10.1007/BF02299733

Hannafin, M., Hill, J. \& Land, S. (1997). Student-centered learning and interactive multimedia: Status, issues, and implications. Contemporary Education, 68(2), 94-99. Retrieved from the ERIC database (EJ553079).

Hartescu, I. (2013). Exploring students' experience of project-based learning in an instructional design course. In EC-TEL Doctoral Consortium (pp. 37-42).

Hermans, R., Tondeur, J., van Braak, J., \& Valcke, M. The impact of primary school teachers' educational beliefs on the classroom use of computers. Computers \& Education, 51(4), 1499-1509. https://doi.org/10.1016/j.compedu.2008.02.001

Johnson, B., \& Christensen, L. (2004). Educational research: Quantitative, qualitative, and mixed approaches (2nd ed.). Boston: Pearson Education.

Jonassen, D. (1995). Constructivism and computer-mediated communication in distance education. American Journal of Distance Education, 9(2), 7-26. https://doi.org/10.1080/08923649509526885

Jonassen, D. H. (1998). Designing constructivist learning environments. In C. M. Reigeluth (Ed.), Instructional-design theories and models (2nd ed.) (pp. 215-239). Mahwah, NJ: Lawrence Erlbaum.

Kalaycı, N. (2008). Yüksek öğretimde proje tabanlı öğrenme projeyi yöneten öğrenciler açısından analiz [Analysing project-based learning from the perspectives of team leader students in higher education]. Education \& Science, 33(147), 85-105.

Karaca, E. (2011). The effects of project based learning approach in pedagogical agent assisted learning environment on students' achievements and attitudes in human computer interaction course (Unpublished master's thesis). Bahcesehir University, İstanbul, Turkey.

Karaman, S., \& Celik, S. (2008). An exploratory study on the perspectives of prospective computer teachers following project-based learning. International Journal of Technology and Design Education, 18(2), 203-215. https://doi.org/10.1007/s10798-006-9021-1

Kılıç, M. (2009). Proje tabanlı öğrenmede web tabanlı araç geliş̧tirilmesi ve kullanımına yönelik ögretmen ve ögrenci görüşleri [Teachers' and students' opinions about developing and using web-based tools concerning project-based learning] (Unpublished master's thesis). Hacettepe University Graduate School of Science and Engineering, Ankara.

Koh, J. H. L., Herring, S. C., \& Hew, K. F. (2010). Project-based learning and student knowledge construction during asynchronous online discussion. The Internet and Higher Education, 13(4), 284-291. https://doi.org/10.1016/j.iheduc.2010.09.003

Krajcik, J. S., Blumenfeld, P., Marx, R. W., Bass, K. M., Fredricks, J., \& Soloway, E. (1998). Inquiry in project-based science classrooms: Initial attempts by middle school students. Journal of the Learning Sciences, 7(3\&4), 313-350. https://doi.org/10.1080/10508406.1998.9672057

Kuş Saillard, E. (2009). Qualitative research projects with NVivo8. Ankara: Anı Yayıncılık.

Land, S. M. \& Hannafin, M. J. (2000). Student-centered learning environments. In D. Jonassen, \& S. Land (Eds.), Theoretical Foundations of Learning Environments (pp. 1-23). Mahwah: Lawrence Erlbaum Associates.

Lang, Q. C. (2005). Pre-service teachers' collaborative project crafting in computer-supported classroom learning environment. Paper presented at AARE 2005: International Educational Research Conference, Sydney, Australia. 
Lary, M. J., Lavigne, S. E., Muma, R. D., Jones, S. E., \& Hoeft, H. J. (1997). Breaking down barriers: Multidisciplinary education model. Journal of Allied Health, 26(2), 63-69.

Lavy, I., \& Shriki, A. (2008). Investigating changes in prospective teachers' views of a 'good teacher' while engaging in computerized project-based learning. Journal of Mathematics Teacher Education, 11(4), 259-284. https://doi.org/10.1007/s10857-008-9073-0

Livingstone, D., \& Lynch, K. (2000). Group project work and student-centred active learning: Two different experiences. Studies in Higher Education, 25(3), 325-345. https://doi.org/10.1080/713696161

Lou, Y., \& Kim MacGregor, S. (2004). Enhancing project-based learning through online between-group collaboration. Educational Research and Evaluation, 10(4-6), 419-440. https://doi.org/10.1080/13803610512331383509

Lou, Y., Abrami, P. C., \& d'Apollonia, S. (2001). Small group and individual learning with technology: A $\begin{array}{lllll}\text { meta-analysis. } & \text { Review of }\end{array}$ https://doi.org/10.3102/00346543071003449

Marshall, J. A., Petrosino, A. J., \& Martin, T. (2010). Preservice teachers' conceptions and enactments of project-based instruction. Journal of Science Education and Technology, 19(4), 370-386. https://doi.org/10.1007/s10956-010-9206-y

Meriam, S. B. (1998). Qualitative research and case study applications in education. San Francisco: Jossey-Bass.

Miles, M. B., \& Huberman, A. M. (1994). Qualitative data analysis (2nd ed.). Thousand Oaks, CA: Sage.

Morgan, A. R. (1987). Project work in open learning. In M. Thorpe, \& D. Grugeon (Eds.), Open learning for adults (pp. 245-251). Harlow, London: Longman.

Nosbush, L. (2006). Learning how to learn in an information age. Retrieved from http://www.mcdowellfoundation.ca/main_mcdowell/projects/research_rep/73_Learning_to_Learn_Informat ion_age.pdf

Özdemir, S., \& Kılıç, E. (2007). Integrating information and communication technologies in the Turkish primary school system. British Journal of Educational Technology, 38(5), 907-916. https://doi.org/10.1111/j.1467-8535.2006.00678.x

Özer, D. Z., \& Özkan, M. (2013). The effect of project-based learning method on science process skills of prospective teachers of science education in biology lessons. International Online Journal of Educational Sciences, 5(3), 635-645. Retrieved from http://www.iojes.net//userfiles/Article/IOJES_720.pdf

Peck, J. K., Peck, W., Sentz, J., \& Zasa, R. (1998). Students' perceptions of literacy learning in a project based curriculum. In E. G. Stutevant, \& J. Dugan (Eds.), Literacy and community: The twentieth yearbook: A peer reviewed publication of the College Reading Association (pp. 94-100). Carrollton, GA: Beacon

Pinho-Lopes, M., \& Macedo, J. (2016). Project-based learning in Geotechnics: Cooperative versus collaborative $\begin{array}{llll}\text { teamwork. European Journal of Engineering Education, 41(1), } & \text { 70-90. }\end{array}$ https://doi.org/10.1080/03043797.2015.1056099

Raes, A., \& Schellens, T. (2016). The effects of teacher-led class interventions during technology-enhanced science inquiry on students' knowledge integration and basic need satisfaction. Computers \& Education, 92, 125-141. https://doi.org/10.1016/j.compedu.2015.10.014

Savery, J. R., \& Duffy, T. M. (1996). Problem based learning: An instructional model and its constructivist framework. In B. G. Wilson (Ed.), Constructivist learning environments: Case studies in instructional design (p. 135-148). New Jersey: Educational Technology Press.

Shi, L., Reeder, K., Slater, T., \& Kristjansson, C. (2004). Tensions in learning content and technology: The experience of education students in a web-based research project. Technology, Pedagogy and Education, 13(1), 43-60. https://doi.org/10.1080/14759390400200172

Springer, L., Stanne, M. E., \& Donovan, S. S. (1999). Effects of small-group learning on undergraduates in science, mathematics, engineering, and technology: A meta-analysis. Review of Educational Research, 69(1), 21-51. https://doi.org/10.3102/00346543069001021

Stemler, S. (2001). An overview of content analysis. Practical Assessment, Research \& Evaluation, 7(17). Retrieved from http://pareonline.net/getvn.asp?v=7\&n=17 
Takeuchi, M. A. (2016). Friendships and group work in linguistically diverse mathematics classrooms: Opportunities to learn for English language learners. Journal of the Learning Sciences, 1-27. https://doi.org/10.1080/10508406.2016.1169422

Thomas, J. W. (2000). A review of research on project-based learning: Report prepared for the Autodesk Foundation. Retrieved from http://www.bie.org/index.php/site/RE/PBL_research/29

Thomas, J. W., Mergendoller, J. R., \& Michaelson, A. (1999). Project-based learning: A handbook for middle and high school teachers. Novato, CA: Buck Institute for Education.

Tondeur, J., Pareja Roblin, N., van Braak, J., Voogt, J., \& Prestridge, S. (2016). Preparing beginning teachers for technology integration in education: Ready for take-off? Technology, Pedagogy and Education, 1-21. https://doi.org/10.1080/1475939X.2016.1193556

Wallace, M., \& Poulson, L. (2003). Critical reading for self-critical writing. In M. Wallace and L. Poulson (Eds.) Learning to Read Critically in Educational Leadership and Management. London: Sage Publications. https://doi.org/10.4135/9781446216576.n1

Ward, D. \& Tiessen, E. (1997). Adding educational value to the web: Active learning with alive pages. Educational Technology, 37(5), 22-28. Retrieved from the ERIC database (EJ552483).

Yavuz, S., \& Coşkun, A. E. (2008). Attitudes and perceptions of elementary teaching through the use of technology in education. Hacettepe University Journal of Education, 34, 276-286. Retrieved from http://www.efdergi.hacettepe.edu.tr/makale_goster.php?id=527

Yildirim, S. (2000). Effects of an educational computing course on preservice and in-service teachers: A discussion and analysis of attitudes and use. Journal of Research on Computing in Education, 32(4), 479-495.

Yıldırım, A., \& Şimşek, H. (2008). Sosyal bilimlerde nitel araştırma yöntemleri [Qualitative research methods for social sciences]. Ankara: Seçkin.

\section{Copyrights}

Copyright for this article is retained by the author(s), with first publication rights granted to the journal.

This is an open-access article distributed under the terms and conditions of the Creative Commons Attribution license (http://creativecommons.org/licenses/by/4.0/). 